\title{
Fertility and acidity status of latossolos (oxisols) under pasture in the Brazilian Cerrado
}

\author{
PEDRO R.S. VENDRAME ${ }^{1}$, OSMAR R. BRITO ${ }^{2}$, MARIA F. GUIMARÃES ${ }^{2}$ \\ ÉDER S. MARTINS ${ }^{3}$ and THIERRY BECQUER ${ }^{4}$ \\ ${ }^{1}$ Departamento de Geociências, Universidade Estadual de Londrina, UEL, Rodovia Celso Garcia Cid \\ Campus Universitário, Caixa Postal 6001, 86051-990 Londrina, PR, Brasil \\ ${ }^{2}$ Departamento de Agronomia, Universidade Estadual de Londrina, UEL, Rodovia Celso Garcia Cid \\ Campus Universitário, Caixa Postal 6001, 86051-970 Londrina, PR, Brasil \\ ${ }^{3}$ Embrapa Cerrados, Km 18, BR-020, Caixa Postal 08223, 73301-970 Planaltina, DF, Brasil \\ ${ }^{4}$ Institut de Recherche pour le Développement, IRD, UMR 210 Eco\&Sols, 2 place Viala \\ Bâtiment 12, 34060 Montpellier, Cedex 1, France
}

Manuscript received on April 9, 2009; accepted for publication on July 12, 2010

\begin{abstract}
The Cerrado region, with over 50 million hectares of cultivated pasture, provides $55 \%$ of Brazilian beef production. Previous investigations have shown that about $70-80 \%$ of this pasture is affected by some kind of degradation, leading to low productivity. However, until now, few surveys have been carried out on a regional scale. The aim of the present work is both to assess the fertility and acidity levels of Cerrado soils under pasture and compare the variability of the soils characteristics on a regional scale. Two soil depths were sampled in different places within the studied area: (1) a surface horizon $(0.0-0.2 \mathrm{~m})$ in order to evaluate its fertility and acidity status for pasture, and (2) a subsurface horizon $(0.6-0.8 \mathrm{~m})$, used for classification. Most of soils had levels of nutrients below the reference values for adequate pasture development. Whatever the texture, about $90 \%$ of soils had low or very low availability of phosphorus. Only 7 to $14 \%$ of soils had low $\mathrm{pH}$, high exchangeable aluminum, and aluminum saturation above the critical acidity level. Except for nitrogen, no significant difference was found between Latossolos Vermelhos and Latossolos Vermelho-Amarelos.
\end{abstract}

Key words: cation exchange capacity, exchangeable aluminum, phosphorus availability, soil degradation, total carbon.

\section{INTRODUCTION}

The Cerrado soils were described as being weathered, highly acidic and containing small amounts of nutrients that are essential for the cultivation of plants (Adamoli et al. 1985). These descriptions correspond mainly to Latossolos, which cover half of the total Cerrado area (Reatto and Martins 2005).

In a study of Latossolos in the Cerrado region, Carmo et al. (1984) showed that kaolinite, gibbsite and iron oxides (hematite and goethite) are the main minerals of the clay fraction, while quartz, anatase and magnetite are the dominant minerals of the sand fraction.

Correspondence to: Pedro Rodolfo Siqueira Vendrame

E-mail: vendrame@uel.br
This mineralogical composition depends mainly on the parent material and extent of weathering where they are found, and has a fundamental influence on the activity of clays (Carvalho Junior 2000). Along with the low levels of organic carbon commonly found in these soils, this low clay activity causes a low cation exchange capacity, which is another of their key characteristics (Gomes et al. 2004)

Despite the fact that Cerrado soils were considered to be of low productivity for a long time, the region has been the focus of intense agricultural expansion since the 1970s. Cattle-raising has become an established activity, with Cerrado currently producing $55 \%$ of beef in Brazil (Anualpec 2006). 
Cultivated pasture covers about 50 million hectares of the Cerrado region (Sano et al. 2008). There are estimates showing that about $70-80 \%$ of this pasture is composed of soils with variable levels of degradation, which results in the low productivity of these areas, as highlighted by Lilienfein et al. (2003) and Brossard and Barcellos (2005). This condition is mainly caused by low biological activity and a lack of essential chemical elements such as nitrogen, phosphorus, potassium, calcium and magnesium. The "nutrient mining" characteristic of this farming activity is revealed by the very small amount of NPK (about $4 \mathrm{~kg} \mathrm{ha}^{-1} \mathrm{yr}^{-1}$ ) that Brazilian pastures received from 1994 to 2002 (Vilela et al. 2004).

Low levels of exchangeable bases lead to soil acidification and increase the levels of exchangeable aluminum. The phytotoxicity of the aluminum in these areas has already been demonstrated by different researchers (Abreu et al. 2003, Wenzl et al. 2003, Mendonça et al. 2006), mainly in Latossolos. Lime and fertilizer inputs might minimize and even eliminate such problems, but technical recommendations are often not implemented by the farmers of the region.

Since the creation of Embrapa Cerrados and the establishment of the Radambrasil project, the characteristics of the Cerrado soils have been intensively studied. However, most of the completed work has only examined the soils under unexploited Cerrado vegetation. The aims of this study are, therefore: i) to assess the fertility status and acidity levels of Latossolos under pasture in the Brazilian Cerrado; ii) to examine the variability of the fertility in the light of soil characteristics as classified by the Brazilian Soil Classification System.

\section{MATERIALS AND METHODS}

\section{STUdy Site AND SAMPLING}

Soils were collected from the Brazilian Cerrado region. Samplings were carried out in two sub-regions situated near the highways GO-060 and BR-154, between the towns of Goiânia, GO, and Barra do Garças, MT $\left(15^{\circ} 34^{\prime} 40^{\prime \prime} \mathrm{S}\right.$ to $16^{\circ} 39^{\prime} 34^{\prime \prime} \mathrm{S}$, and $49^{\circ} 20^{\prime} 48^{\prime \prime} \mathrm{W}$ to $\left.52^{\circ} 17^{\prime} 52^{\prime \prime} \mathrm{W}\right)$, and northwest of Minas Gerais, including the towns of Unaí and Paracatu $\left(16^{\circ} 35^{\prime} 24^{\prime \prime} \mathrm{S}\right.$ to $16^{\circ} 52^{\prime} 48^{\prime \prime} \mathrm{S}$, and $46^{\circ} 27^{\prime} 36^{\prime \prime} \mathrm{W}$ to $46^{\circ} 48^{\prime} 36^{\prime \prime} \mathrm{W}$ ) (Fig. 1).
Geological and pedological maps were used in an attempt to select sampling sites with high soil variability. A total of 74 composite samples were taken from two depths $(0.0-0.2 \mathrm{~m}$ and $0.6-0.8 \mathrm{~m})$. Each of these was composed of two cores taken with an Edelman auger. The ones from 0.0-0.2 m layer represent the surface horizon where soil fertility and acidity status were analyzed, while the others from $0.6-0.8 \mathrm{~m}$ layer represent the subsurface horizon used for soil classification. That was based on the Brazilian Soil Classification System (Santos et al. 2006), according to which all the soil samples were Latossolos. Taking into account the matrix Munsell color measured in the subsurface horizons, soils are divided into two suborders: Latossolos Vermelhos (LV) and Latossolos Vermelho-Amarelos (LVA). Within these suborders, three texture groups can be defined: very clayey (clay $\left.>600 \mathrm{~g} \mathrm{~kg}^{-1}\right)$, clayey $\left(350 \mathrm{~g} \mathrm{~kg}^{-1}<\right.$ clay $\left.<600 \mathrm{~g} \mathrm{~kg}^{-1}\right)$ and coarse-loamy $\left(15 \mathrm{~g} \mathrm{~kg}^{-1}<\right.$ clay $<35 \mathrm{~g} \mathrm{~kg}^{-1}$ ) (Table I). The mineralogical characteristics, such as the $\mathrm{Ki}$ and $\mathrm{Kr}$ ratios, kaolinite and gibbsite content of these Latossolos, can be found in Vendrame (2008).

All the selected areas were covered with pasture. Sampling sites were geo-referenced by GPS (Global Positioning System) equipment. After collection, packaging and identification, soils were sent to the Embrapa Cerrados soils laboratory in Planaltina, DF, where they were dried and screened through a $2 \mathrm{~mm}$ stainless steel sieve.

\section{SOIL ANALYSIS}

Physical and chemical analyses were conducted at Embrapa Cerrados soils laboratory following the methodology established by Claessen (1997). The following characteristics were determined: particle size distribution; $\mathrm{pH}$ in water and $\mathrm{KCl}$ (ratio 1:2.5); available phosphorus (P) and potassium (K), extracted with Mehlich-1 solutions $\left(0.0125 \mathrm{~mol} \mathrm{~L}^{-1}\right.$ of $\mathrm{H}_{2} \mathrm{SO}_{4}$ and $0.050 \mathrm{~mol} \mathrm{~L}^{-1}$ of $\mathrm{HCl}$ ); exchangeable aluminum (Al), calcium ( $\mathrm{Ca})$ and magnesium $(\mathrm{Mg})$, extracted with $\mathrm{KCl} 1 \mathrm{~mol} \mathrm{~L}^{-1}$; and $\mathrm{H}$ $+\mathrm{Al}$, extracted with calcium acetate solution $0.5 \mathrm{~mol} \mathrm{~L}^{-1}$ at $\mathrm{pH} 7.0$ and titrated with $\mathrm{NaOH} 0.0606 \mathrm{~mol} \mathrm{~L}^{-1}$. With the results obtained from the analyses of the exchangeable charges of the soils, the sum of exchangeable bases (EB), the cationic exchange capacity at $\mathrm{pH} 7.0\left(\mathrm{CEC}_{\mathrm{pH}}\right)$, 


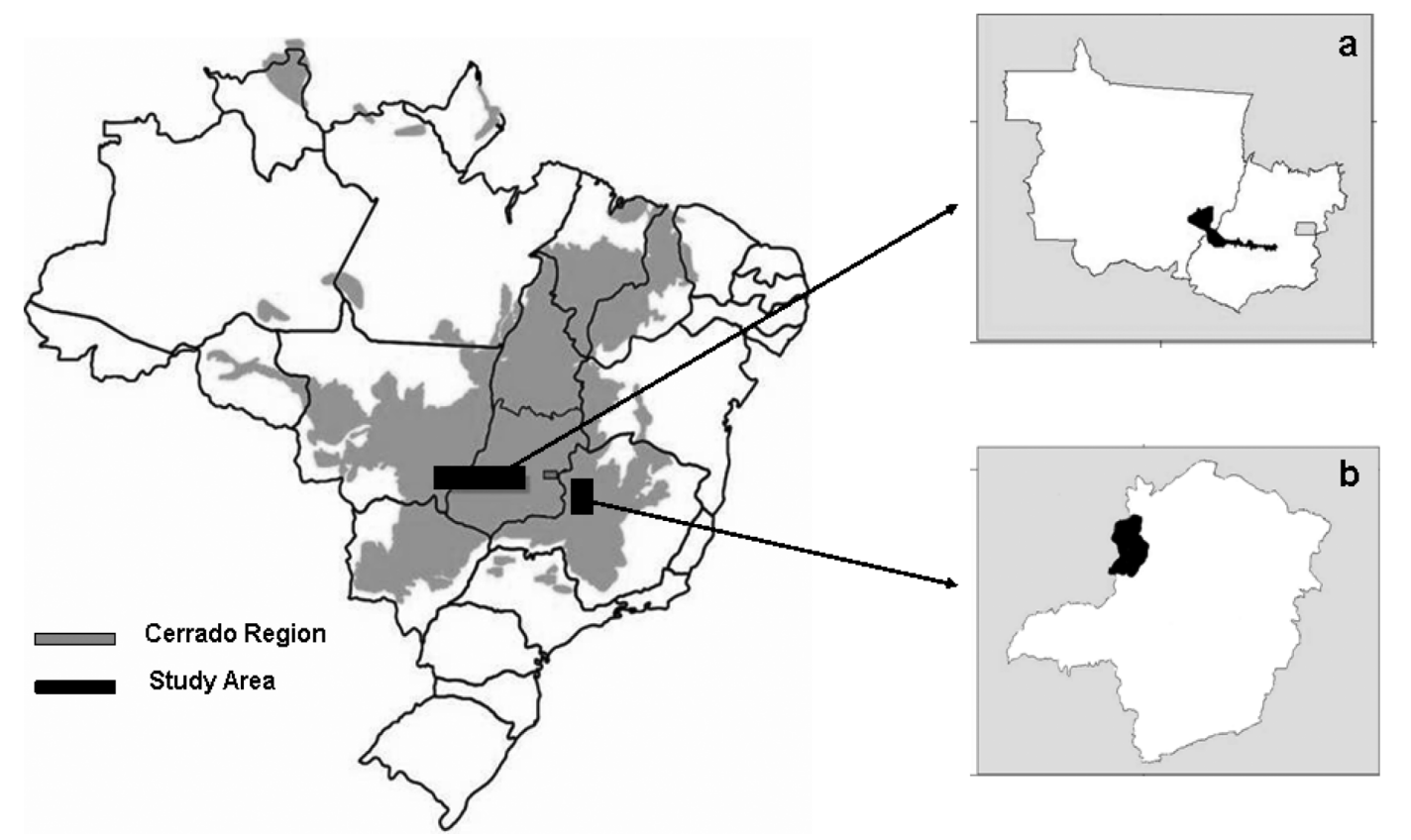

Fig. 1 - Cerrado region in Central Brazil and detail showing the study area: a) Goiás and Mato Grosso States; b) Minas Gerais State. (Adapted from Embrapa Cerrados).

the effective cationic exchange capacity (ECEC), the base saturation (V) and the aluminum saturation (m) were calculated. The total carbon $(\mathrm{C})$ and nitrogen $(\mathrm{N})$ levels were determined using a Perkin Elmer 2400 Series II CNHS Analyzer.

The classification of the soils as Latossolos was based on field observations, i.e. depth of the latosolic horizon, content of primary minerals, as well as on some analytical determinations, i.e. the particle size distribution and the molecular ratio $\mathrm{SiO}_{2} / \mathrm{Al}_{2} \mathrm{O}_{3}$ (Ki) (data not shown). Suborders were determined according to wet soil color of the subsurface horizon using a Munsell Soil Color Chart. Texture groups were defined according to the particle size distribution (Santos et al. 2006).

The data were submitted to descriptive statistical analyses (Statistica 5.5, Statsoft, Inc.) aiming at obtaining the mean, the range of the variations (minimum and maximum), and frequency distribution for each one of the chemical characteristics analyzed. As the precondition of normality was not fulfilled, the data were arranged by ranking before being subjected to ANOVA to test the effects of soil characteristics (soil type, texture). Differences between group means were tested using the Fisher LSD test.

\section{RESULTS AND DISCUSSIONS}

\section{SOIL FERTILITY AND ACIDITY}

The mean values, variation range and frequency distribution for the evaluated variables, considering the full analysis of the studied soils, are shown in Figure 2.

The $\mathrm{pH}_{\mathrm{H} 2 \mathrm{O}}$ values range from 4.6 to 8.1 , with a mean of 5.6 (Fig. 2). These values are higher than those reported by Lopes and Cox (1977) for unexploited soils from the Cerrado region, in which $48 \%$ had $\mathrm{pH}_{\mathrm{H} 2 \mathrm{O}}$ $<5.1$. Most of the soils sampled for our study (78\%) had values between 5.2 and 6.3 , still within medium or adequate levels. Only 10 samples had values considered to be low $\left(\mathrm{pH}_{\mathrm{H} 20}<5.1\right)$ according to the classification presented by Sousa and Lobato (2004). Soil pH determines the plant-availability of many nutrients. In Latossolos, the $\mathrm{P}$ availability is particularly reduced because of strong sorption onto oxides at $\mathrm{pH}<5$ (Friesen et al. 1997). The high $\mathrm{pH}$ values found in some samples may be linked to excessive liming. However, the distribution frequency of $\mathrm{pH}_{\mathrm{KCl}}$ values is similar to that presented by Lopes and Cox (1977), despite the occurrence of higher values in soils under pasture than in those under unexploited Cerrado vegetation. 


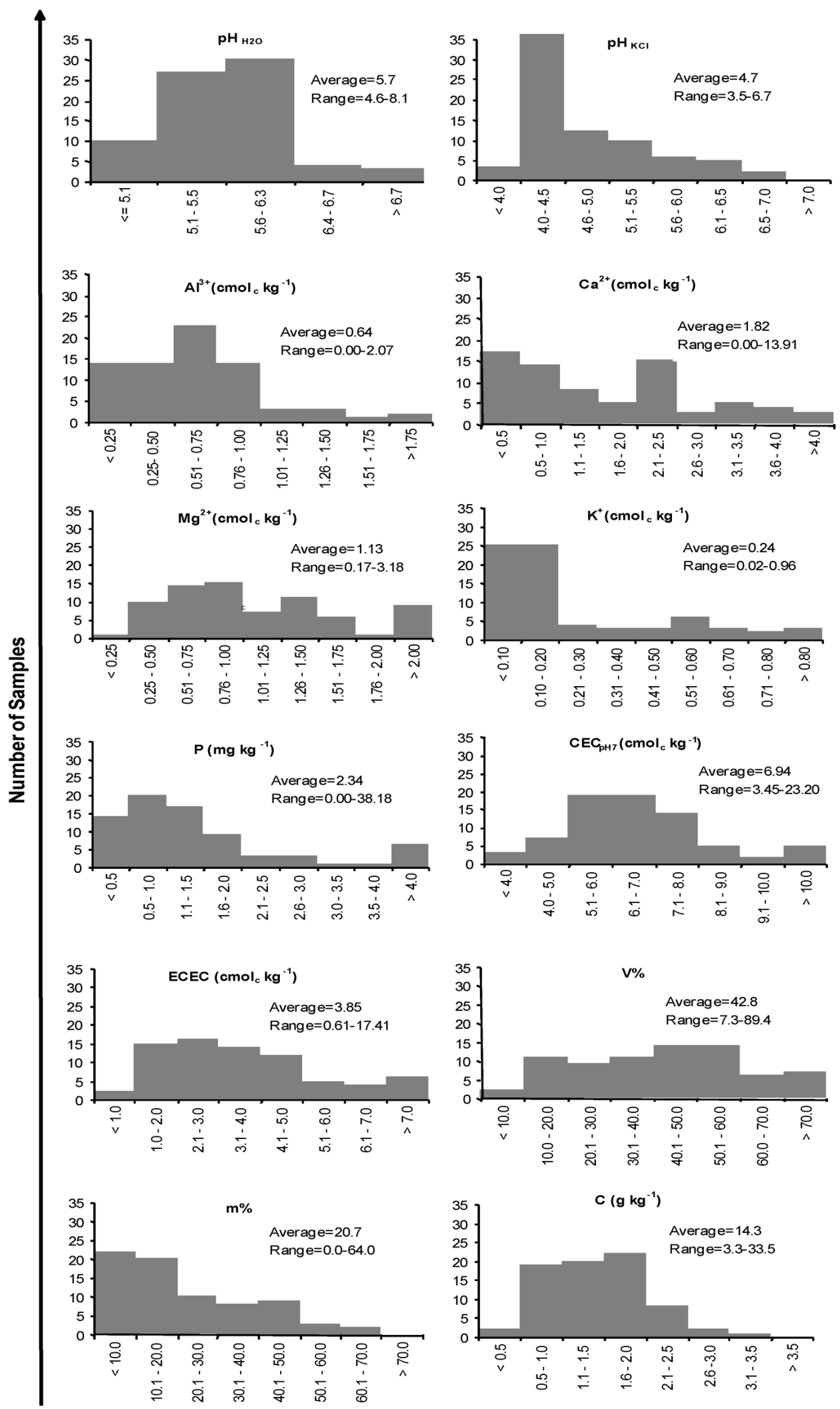

Fig. 2 - Classes and frequency distribution of the chemical characteristics evaluated in the $0.0-0.2 \mathrm{~m}$ horizon of Latossolos under pasture in the Brazilian Cerrado region. 
The mean level of exchangeable $\mathrm{Al}$ was $0.65 \mathrm{cmol}_{\mathrm{c}}$ $\mathrm{kg}^{-1}$, with a range of $0-2.07 \mathrm{cmol}_{\mathrm{c}} \mathrm{kg}^{-1}$. Only $12 \%$ of samples were above the critical level of $1 \mathrm{cmol}_{\mathrm{c}} \mathrm{dm}^{-1}$ proposed by Luz et al. (2004). These values are close to those observed by Lopes and Cox (1977) in $0-15 \mathrm{~cm}$ layer of soil under unexploited Cerrado, which had a mean value of $0.56 \mathrm{cmol}_{\mathrm{c}} \mathrm{dm}^{-1}$.

Regarding the exchangeable $\mathrm{Ca}$ levels, a mean value of $1.82 \mathrm{cmol}_{\mathrm{c}} \mathrm{kg}^{-1}$ was found, with a range of $0-13.91 \mathrm{cmol}_{\mathrm{c}} \mathrm{kg}^{-1}$. Up to $42 \%$ of samples had $\mathrm{Ca}$ levels below $1.00 \mathrm{cmol}_{\mathrm{c}} \mathrm{kg}^{-1}$, which is considered to be the critical level for pastures in the Cerrado region (Macedo 2004). As regards the exchangeable Mg levels, a mean value of $1.13 \mathrm{cmol}_{\mathrm{c}} \mathrm{kg}^{-1}$ and a range between 0.17 and $3.18 \mathrm{cmol}_{\mathrm{c}} \mathrm{kg}^{-1}$ were found. Considering that the limiting value for exchangeable $\mathrm{Mg}$ is $0.50 \mathrm{cmol}_{\mathrm{c}}$ $\mathrm{dm}^{-1}, 15 \%$ of samples are within this category (Macedo 2004). The wide ranges observed for $\mathrm{Ca}$ and $\mathrm{Mg}$ levels may be associated to the fact that samplings were made on a soil under pasture that belongs to different landowners who may or may not apply fertilizers and lime. There are samples with very high levels of $\mathrm{Ca}$ and $\mathrm{Mg}$ and, in 39\% of the analyzed soils (data not shown), the $\mathrm{Mg} / \mathrm{Ca}$ ratio was above 1 , which demonstrates the inadequate liming management of soils under pasture in the Cerrado region. When liming soil, it is always advisable to consider the $\mathrm{Ca}^{2+}$ and $\mathrm{Mg}^{2+}$ ratios since an excess of one may interfere in the dynamics of the other, adversely affecting soil adsorption and plant absorption processes. In addition, imbalances between levels of $\mathrm{Ca}$ and $\mathrm{Mg}$ in the soil may change the availability of other macro- and micro-nutrients (Orlando Filho et al. 1996, Vitti et al. 2006).

The mean $\mathrm{V}$ value of the soils was 42.8 , with a range between 7.3 and 89.4. The high content of exchangeable bases (EB), although not directly influencing the levels of exchangeable $\mathrm{Al}$, has a pronounced effect on the $\mathrm{Al}$ saturation level (m). The mean value of $59 \%$ found by Lopes and Cox (1977) during their investigations is far from the $24 \%$ calculated in the present study. Only $7 \%$ of the soils had Al saturation above the critical level of $50 \%$ proposed by Luz et al. (2004).

The first studies on chemical fertility of the soils of the Cerrado region revealed high acidity and exchangeable $\mathrm{Al}$ content as being the main constraints for the development of farming and cattle-raising in the region (Lopes and Cox 1977, Adamoli et al. 1985). To counter the effect of acidity, the main method of correction proposed was the addition of lime. Exchangeable Al has been used to calculate lime requirement in the Cerrado region (Sousa and Lobato 2004). However, Ritchey et al. (1982) considered the deficiency of basic elements, particularly calcium, to be the main limitation to plant growth in the Cerrado region. Our study largely corroborates the data presented by Ritchey et al. (1982).

The mean content of exchangeable $\mathrm{K}$ was 0.24 $\mathrm{cmol}_{\mathrm{c}} \mathrm{kg}^{-1}$, with a range between 0.02 and $0.96 \mathrm{cmol}_{\mathrm{c}}$ $\mathrm{kg}^{-1}$. Values below $0.25 \mathrm{cmol}_{\mathrm{c}} \mathrm{dm}^{-1}$ are considered low for pasture (Macedo 2004), and $73 \%$ of samples fell into this category. These values are mainly due to both the lack of replacement of the $\mathrm{K}$ removed by the cattle-raising activity and the low rates of nutrients recycling in pastures under inadequate conservation conditions (Vilela et al. 2004).

The available P ranged from 0.02 to $38.20 \mathrm{mg} \mathrm{kg}^{-1}$, with a mean of $2.30 \mathrm{mg} \mathrm{kg}^{-1}$. The interpretation of phosphorus levels established by Sousa et al. (2001) for forage grasses, which vary with texture, is given in the next section. The low availability of $\mathrm{P}$ is one of the main factors limiting pasture development in the region. According to Silva et al. (1997), the low P availability in the soils from the Cerrado region is due to the lack of regular applications of phosphate fertilizers, as well as to a strongly negative phosphorus interaction with iron and aluminum oxides that are present in the soils of this region.

The $\mathrm{CEC}_{\mathrm{pH} 7}$ mean value of the soils was $6.94 \mathrm{cmol}_{\mathrm{c}}$ $\mathrm{kg}^{-1}$, with a range between 3.45 and $23.55 \mathrm{cmol}_{\mathrm{c}} \mathrm{kg}^{-1}$. Regarding ECEC values, a mean value of $3.85 \mathrm{cmol}_{\mathrm{c}}$ $\mathrm{kg}^{-1}$ was found, with a range between 0.61 and 17.41 $\mathrm{cmol}_{\mathrm{c}} \mathrm{kg}^{-1}$. Due to high $\mathrm{Ca}$ and $\mathrm{Mg}$ contents in some samples, the ECEC mean values are higher than the 1.10 $\mathrm{cmol}_{\mathrm{c}} \mathrm{dm}^{-1}$ presented by Lopes and Cox (1977).

The total $\mathrm{C}$ in the soils varies from $3.3 \mathrm{~g} \mathrm{~kg}^{-1}$ to $33.5 \mathrm{~g} \mathrm{~kg}^{-1}$, with mean values of $14.3 \mathrm{~g} \mathrm{~kg}^{-1}$. These values are below the ones presented $\left(\mathrm{C}=17.0 \mathrm{~g} \mathrm{~kg}^{-1}\right)$ by Marques et al. (2004) for unexploited Cerrado soils, and far below the mean values of $22.0 \mathrm{~g} \mathrm{~kg}^{-1}$ measured by Lilienfein et al. (2003) in Cerrado soils under degraded pastures in the Triângulo Mineiro region. 
These authors found that, in the same region, pastures in good condition presented mean total $\mathrm{C}$ levels of $27.0 \mathrm{~g} \mathrm{~kg}^{-1}$.

\section{Soil ClassificATION}

The number of samples of each class, as well as the results of matrix Munsell color determinations and granulometric analyses, are presented in Table I.

According to the matrix Munsell color, 44 samples are Latossolos Vermelho-Amarelos (LVA), and 30 samples are Latossolos Vermelhos (LV). Within the LVA, 5 samples are very clayey, 28 are clayey and 11 are coarse-loamy. Within the LV, 13 samples are very clayey, 14 are clayey and 3 are coarse-loamy.

Clayey Latossolos have a darker color than coarseloamy and very clayey Latossolos. The maximum red coloration measured does not exceed $2.5 \mathrm{YR}$ in $\mathrm{LV}$, which leads to small variations between the color of LV and LVA. However, the clay levels range widely between 150 and $820 \mathrm{~g} \mathrm{~kg}^{-1}$ taking into account soils with coarse-loamy and very clayey textures (Table I).

The mean chemical composition measured in LV and LVA and the different textural groups defined above are shown in Table II.

Although levels of $\mathrm{pH}, \mathrm{Ca}, \mathrm{Mg}, \mathrm{K}, \mathrm{P}, \mathrm{C}$ and $\mathrm{N}$ were higher in the LV than in the LVA, the difference was only significant (at $\mathrm{p}<0.05$ ) for $\mathrm{N}$. On the other hand, some significant differences were found regarding textural classification. The exchangeable $\mathrm{Ca}$ and $\mathrm{Mg}$ levels, along with its related variables $\left(\mathrm{CEC}_{\mathrm{pH}}, \mathrm{ECEC}, \mathrm{EB}\right.$ and $\mathrm{V}$ ), are significantly higher in clayey and very clayey Latossolos. These results can be attributed to the higher C content found in these soils (Table II). The contribution of organic matter to the cation exchange capacity is well known (Raij 1991, Sousa and Lobato 2004). The results of this study corroborate those presented by Zinn et al. (2005), who suggested that the sum of silt and clay levels may be used as an indication of $\mathrm{C}$ stocks in the soils of the Cerrado region. Other authors have also noted a positive correlation between levels of organic carbon and clay in soil (Schimel et al. 1985, Spain 1990), attributing this result to the fact that the absorption of organic molecules at clay surfaces provides a mechanism for stabilization and protection against microbial attack (Ladd et al. 1996).
The levels of available $\mathrm{P}$ and exchangeable $\mathrm{K}$ did not differ significantly among the textures (Table II). As the soils have a greater capacity to adsorb $\mathrm{P}$ with increasing clay content, the texture should be taken into account for the interpretation of plant $\mathrm{P}$ requirement (Novais and Smyth 1999). By using the interpretation criteria for phosphorus levels established by Sousa et al. (2001) for forage grasses, it was found that, whatever the texture considered, about $90 \%$ of soils had low or very low availability of phosphorus, i.e. $96 \%$ of coarse-loamy Latossolos have $\mathrm{P}<5.1 \mathrm{mg} \mathrm{kg}^{-1}, 87 \%$ of clayey Latossolos have $\mathrm{P}<3.1 \mathrm{mg} \mathrm{kg}^{-1}$, and $94 \%$ of very clayey Latossolos have $\mathrm{P}<1.6 \mathrm{mg} \mathrm{kg}^{-1}$ (Fig. 3).

The levels of $\mathrm{K}$ and $\mathrm{P}$ were far below the ones suggested for good pasture development, and corroborated the data presented by Vilela et al. (2004) who showed that Brazilian pastures received about a mere $4 \mathrm{~kg} \mathrm{ha}^{-1} \mathrm{yr}^{-1}$ from 1994 to 2002 . The degradation of pasture over time is the major obstacle to the establishment of sustainable cattle-raising, and low soil fertility is one of the most important factors that explain the degradation of pastures in this region.

Levels of exchangeable $\mathrm{Al}^{3+}$ were significantly higher in very clayey Latossolos, differing only from values observed in clayey Latossolos. With regard to Al saturation (m), it was found that clayey Latossolos displayed the lowest means, which is in accordance with the trend observed for absolute $\mathrm{Al}^{3+}$ levels. The fact that clayey Latossolos exhibited lower means for aluminum-related variables is directly associated to their acidity $\left(\mathrm{pH}_{\mathrm{KCl}}\right.$ values), which was significantly lower than the one observed in soils of coarse-loamy and very clayey textures (Table II) (Nachtigall and Vahl 1989).

Although the $\mathrm{Ca}$ and $\mathrm{Mg}$ levels were significantly higher in clayey and very clayey texture soils, levels of $\mathrm{Al}$ in very clayey Latossolos are similar to those observed in coarse-loamy ones. As a consequence, it is necessary to add larger amounts of bases to obtain complete aluminum neutralization in this textural class, since the degree of buffering is strongly related to the amount of $\mathrm{C}$ and clay (Mendonça et al. 2006).

\section{CONCLUSIONS}

Although the soil acidity is considered as a major feature that can explain the degradation of pastures, only 
TABLE I

Class, texture, number of samples per group, matrix Munsell color and particle size distribution of Latossolos under pasture in the Brazilian Cerrado region.

\begin{tabular}{|c|c|c|c|c|c|c|c|}
\hline \multirow{2}{*}{ Class } & \multirow{2}{*}{ Texture } & \multirow{2}{*}{$\begin{array}{c}\text { Number of } \\
\text { samples }\end{array}$} & \multirow{2}{*}{ Matrix Munsell color } & Clay $^{1}$ & Silt $^{1}$ & Fine sand ${ }^{1}$ & Coarse sand $^{1}$ \\
\hline & & & & \multicolumn{4}{|c|}{$\mathrm{g} \mathrm{kg}^{-1}$} \\
\hline \multirow{6}{*}{ LVA } & \multirow{2}{*}{ Very clayey } & \multirow{2}{*}{5} & \multirow{2}{*}{ 5YR 4/6-7.5 YR 5/8 } & 700 & 110 & \multirow{2}{*}{$\begin{array}{c}\mathbf{4 2} \\
20-100\end{array}$} & \multirow{2}{*}{$\begin{array}{c}146 \\
80-210\end{array}$} \\
\hline & & & & $670-720$ & $50-160$ & & \\
\hline & \multirow{2}{*}{ Clayey } & \multirow{2}{*}{28} & \multirow{2}{*}{ 5YR 4/4-7.5YR 5/8 } & 486 & 64 & 129 & 321 \\
\hline & & & & $360-600$ & $10-170$ & $20-320$ & $180-450$ \\
\hline & \multirow{2}{*}{ Coarse-loamy } & \multirow{2}{*}{11} & \multirow{2}{*}{ 5YR 4/6-7.5 YR 6/8 } & 290 & 45 & 228 & 437 \\
\hline & & & & $210-350$ & $0-130$ & $70-420$ & $360-550$ \\
\hline \multirow{6}{*}{ LV } & \multirow{2}{*}{ Very clayey } & \multirow[t]{2}{*}{13} & \multirow{2}{*}{ 2.5YR 3/6-5YR 3/4 } & 715 & 105 & 38 & 142 \\
\hline & & & & $650-820$ & $70-190$ & $20-90$ & $60-200$ \\
\hline & \multirow{2}{*}{ Clayey } & \multirow{2}{*}{14} & \multirow{2}{*}{ 2.5YR $2.5 / 4-2.5$ YR $4 / 8$} & 509 & 89 & 122 & 281 \\
\hline & & & & $430-600$ & $10-150$ & $30-280$ & $150-370$ \\
\hline & \multirow{2}{*}{ Coarse-loamy } & \multirow{2}{*}{3} & \multirow{2}{*}{$2.5 \mathrm{YR} 4 / 6-5 \mathrm{YR} 3 / 2$} & 240 & 23 & 200 & $\mathbf{5 3 7}$ \\
\hline & & & & $190-340$ & $0-50$ & $70-290$ & $520-570$ \\
\hline
\end{tabular}

Mean values (bold), minimum and maximum (italics).

TABLE II

Comparison of topsoil (0.0-0.2 $\mathrm{m}$ ) chemical properties (mean \pm standard deviation) according to their classification in the Brazilian Soil Classification System (Santos et al. 2006).

\begin{tabular}{|c|c|c|c|c|c|}
\hline \multirow{2}{*}{ Variables } & \multicolumn{2}{|c|}{ Color } & \multicolumn{3}{|c|}{ Texture } \\
\hline & LV & LVA & Very clayey & Clayey & Coarse-loamy \\
\hline $\mathrm{pH}_{\mathrm{H} 2 \mathrm{O}}$ & $5.73 \pm 0.65(\mathrm{~A})$ & $5.64 \pm 0.55(\mathrm{~A})$ & $5.60 \pm 0.74(a)$ & $5.76 \pm 0.53(\mathrm{a})$ & $5.51 \pm 0.52(\mathrm{a})$ \\
\hline $\mathrm{pH}_{\mathrm{KCl}}$ & $4.79 \pm 0.74(\mathrm{~A})$ & $4.73 \pm 0.70(\mathrm{~A})$ & $4.54 \pm 0.71(b)$ & $4.91 \pm 0.73(\mathrm{a})$ & $4.55 \pm 0.56(b)$ \\
\hline $\mathrm{Al}\left(\mathrm{cmol}_{\mathrm{c}} \mathrm{kg}^{-1}\right)$ & $0.69 \pm 0.37(\mathrm{~A})$ & $0.60 \pm 0.46(\mathrm{~A})$ & $0.89 \pm 0.47$ (a) & $0.52 \pm 0.41(b)$ & $0.64 \pm 0.21(\mathrm{ab})$ \\
\hline $\mathrm{K}\left(\mathrm{cmol}_{\mathrm{c}} \mathrm{kg}^{-1}\right)$ & $0.26 \pm 0.26(\mathrm{~A})$ & $0.23 \pm 0.21(\mathrm{~A})$ & $0.29 \pm 0.27$ (a) & $0.25 \pm 0.23(\mathrm{a})$ & $0.16 \pm 0.18(\mathrm{a})$ \\
\hline $\mathrm{Ca}\left(\mathrm{cmol}_{\mathrm{c}} \mathrm{kg}^{-1}\right)$ & $2.18 \pm 2.63(\mathrm{~A})$ & $1.58 \pm 1.35(\mathrm{~A})$ & $1.82 \pm 1.59(\mathrm{a})$ & $2.16 \pm 2.25(\mathrm{a})$ & $0.74 \pm 1.01(b)$ \\
\hline $\operatorname{Mg}\left(\mathrm{cmol}_{\mathrm{c}} \mathrm{kg}^{-1}\right)$ & $1.17 \pm 0.74(\mathrm{~A})$ & $1.10 \pm 0.65(\mathrm{~A})$ & $1.18 \pm 0.61(a)$ & $1.26 \pm 0.73(\mathrm{a})$ & $0.66 \pm 0.37(b)$ \\
\hline $\mathrm{P}\left(\mathrm{mg} \mathrm{kg}^{-1}\right)$ & $3.05 \pm 7.14(\mathrm{~A})$ & $1.86 \pm 3.32(\mathrm{~A})$ & $3.01 \pm 8.54$ (a) & $2.29 \pm 3.94(a)$ & $1.52 \pm 0.89(a)$ \\
\hline $\mathrm{CEC}\left(\mathrm{cmol}_{\mathrm{c}} \mathrm{kg}^{-1}\right)$ & $7.47 \pm 3.34(\mathrm{~A})$ & $6.58 \pm 2.14(\mathrm{~A})$ & $7.08 \pm 1.58$ (a) & $7.30 \pm 3.26(\mathrm{a})$ & $5.54 \pm 1.35(\mathrm{~b})$ \\
\hline $\operatorname{ECEC~}\left(\mathrm{cmol}_{\mathrm{c}} \mathrm{kg}^{-1}\right)$ & $4.33 \pm 3.11(\mathrm{~A})$ & $3.35 \pm 2.10(\mathrm{~A})$ & $4.20 \pm 1.98$ (a) & $4.20 \pm 2.91(\mathrm{a})$ & $2.20 \pm 1.30(\mathrm{~b})$ \\
\hline $\mathrm{EB}\left(\mathrm{cmol}_{\mathrm{c}} \mathrm{kg}^{-1}\right)$ & $3.64 \pm 3.20(\mathrm{~A})$ & $2.92 \pm 2.01(\mathrm{~A})$ & $3.30 \pm 2.04$ (a) & $3.68 \pm 2.86(a)$ & $1.56 \pm 1.43(\mathrm{~b})$ \\
\hline $\mathrm{V}(\%)$ & $44.4 \pm 20.8(\mathrm{~A})$ & $41.7 \pm 19.7(\mathrm{~A})$ & $44.3 \pm 18.3(a)$ & $46.9 \pm 18.9(a)$ & $27.4 \pm 20.1(b)$ \\
\hline $\mathrm{m}(\%)$ & $22.7 \pm 17.3(\mathrm{~A})$ & $21.0 \pm 17.0(\mathrm{~A})$ & $24.9 \pm 15.1(\mathrm{a})$ & $15.5 \pm 13.8(b)$ & $37.2 \pm 19.0(\mathrm{a})$ \\
\hline $\mathrm{C}\left(\mathrm{g} \mathrm{kg}^{-1}\right)$ & $15.8 \pm 5.7(\mathrm{~A})$ & $13.3 \pm 6.2(\mathrm{~A})$ & $15.5 \pm 5.0(\mathrm{a})$ & $15.3 \pm 6.4(\mathrm{a})$ & $9.6 \pm 4.4(b)$ \\
\hline $\mathrm{N}\left(\mathrm{g} \mathrm{kg}^{-1}\right)$ & $1.8 \pm 1.9(\mathrm{~A})$ & $1.3 \pm 1.3(\mathrm{~B})$ & $2.1 \pm 0.5(\mathrm{a})$ & $1.5 \pm 1.3(\mathrm{a})$ & $0.9 \pm 0.3(b)$ \\
\hline
\end{tabular}

Comparison of means by the Fisher LSD test. Elements with the same letter are not significantly different at $\mathrm{p}<0.05$ - capital letters are for comparison of the color; small letters are for comparison of the texture. 

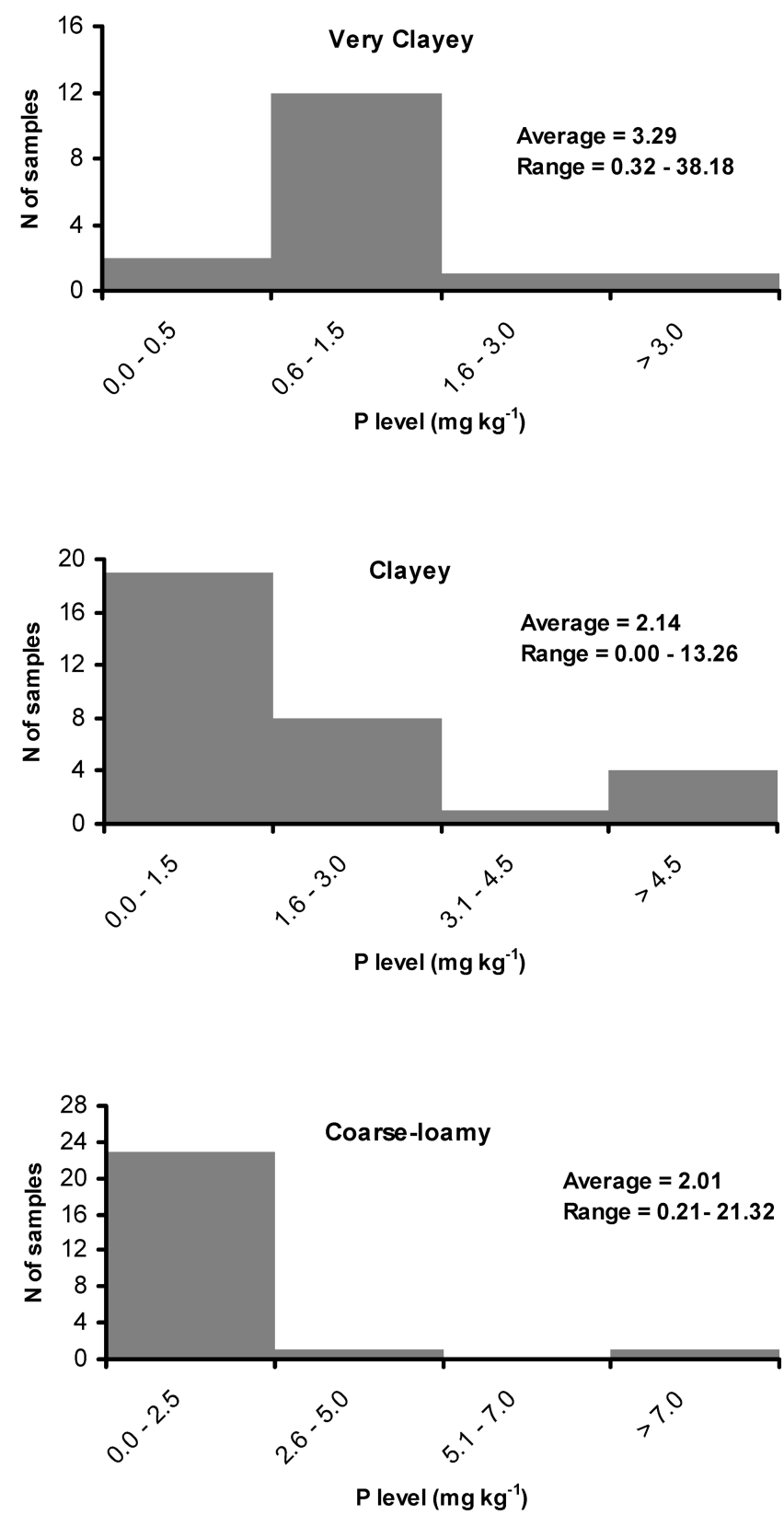

Fig. 3 - Classes and frequency distribution for phosphorus levels according to Sousa et al. (2001), for forage grasses.

7 to $14 \%$ of studied Latossolos had low $\mathrm{pH}$, high exchangeable aluminum and aluminum saturation above the critical acidity level. The levels of exchangeable $\mathrm{Ca}$ and $\mathrm{Mg}$ are higher than those reported for unexploited soils, but that of exchangeable aluminium is comparable, indicating that liming influences predominantly the aluminum saturation of the soil, whereas it does not act noticeably on the exchangeable aluminum. Phosphorus and potassium deficiencies are the main drawback: up to $90 \%$ of studied Latossolos had low or very low availability of P; more than $70 \%$ of the soils had low levels of K. Forty-two and $15 \%$ of the soils were also deficient in exchangeable $\mathrm{Ca}$ and $\mathrm{Mg}$, respectively. These results are attributed to the removal of nutrients by grazing and to the insignificant fertilization that Brazilian pastures received. 
Although levels of $\mathrm{pH}, \mathrm{Ca}, \mathrm{Mg}, \mathrm{K}, \mathrm{P}, \mathrm{C}$ and $\mathrm{N}$ under pastures are higher in Latossolos Vermelhos than in Vermelho-Amarelos, only the $\mathrm{N}$ difference was statistically significant. The exchangeable $\mathrm{Ca}$ and $\mathrm{Mg}, \mathrm{CEC}$, ECEC and $\mathrm{C}$ content were significantly higher in clayey and very clayey Latossolos than in the coarse-loamy ones. The textural characteristics of the soils seemed to be the most important factor controlling soil fertility.

It is known that the Cerrado soils are weathered and highly acidic, and that they contain small amounts of nutrients that are essential for the cultivation of plants. We infer that acidity levels in these pastures were improved in comparison with the unexploited soils. However, the P and $\mathrm{K}$ levels and, to a lower extent, the $\mathrm{Ca}$ one are still low in pastures, which probably compromises the establishment of sustainable cattleraising in this region.

\section{ACKNOWLEDGMENTS}

The authors would like to thank the Institut de Recherche pour le Développement, France, for financial support; Nirceu Werneck Linhares and Diogo Néia Eberhardt for helping with the soil analyses, and Antônio Carlos Gomes for his support during statistical analysis.

\section{RESUMO}

A região do Cerrado, com 50 milhões de hectares de pastagens cultivadas, responde por $55 \%$ da carne bovina produzida no Brasil. Há estimativas indicando que entre 70 e $80 \%$ destas pastagens apresentam algum grau de degradação, o que leva a baixa produtividade. No entanto, até o presente, poucos trabalhos foram desenvolvidos em escala regional. O objetivo deste trabalho foi avaliar a fertilidade e a acidez de Latossolos sob pastagens na região do Cerrado e comparar a variabilidade das características dos solos em escala regional. A amostragem foi realizada em duas profundidades, superficial $(0,0-0,2 \mathrm{~m})$ para avaliação da fertilidade e acidez e subsuperficial $(0,6-$ $0,8 \mathrm{~m}$ ), utilizada para classificar os solos. A maioria dos solos apresentou teores de nutrientes abaixo do recomendado para o adequado desenvolvimento das pastagens. Independentemente da textura, aproximadamente $90 \%$ dos solos apresentaram baixa ou muito baixa disponibilidade de P. Apenas 7-14\% dos solos apresentaram baixo $\mathrm{pH}$, alta saturação por $\mathrm{Al}$ e acidez acima do nível crítico. Exceto para o N, não houve diferença significativa nos níveis de fertilidade e acidez entre os Latossolos Vermelhos e os Latossolos Vermelho-Amarelos.

Palavras-chave: capacidade de troca de cátions, alumínio trocável, disponibilidade de fósforo, degradação do solo, carbono total.

\section{REFERENCES}

Abreu CH, Muraoka T And Lavorante AF. 2003. Relationship between acidity and chemical properties of Brazilians soils. Sci Agric 60: 337-343.

Adamoli J, Macedo J, Azevedo LG and Madeira Neto JS. 1985. Caracterização da região dos cerrados. In: Solos dos cerrados: tecnologias e estratégias de manejo. Goedert WJ (Ed), Nobel, São Paulo; EMBRAPACPAC, Brasília, DF, Brasil, p. 33-74.

ANUALPEC. 2006. Anuário da pecuária brasileira. Instituto FNP, Brasília, DF, Brasil, 369 p.

Brossard M ANd BARCEllos AO. 2005. Conversão do cerrado em pastagens cultivadas e funcionamento de latossolos. Cader Ci Tecnol 22: 153-168.

CARmo DN, Curi N And Resende M. 1984. Caracterização e gênese de Latossolos da região do Alto ParanaíbaMG. R Bras Ci Solo 8: 235-240.

CARVAlho JUNior IA. 2000. Influência da mineralogia e da matéria orgânica na agregação, cor e radiometria de solos altamente intemperizados do Estado de Minas Gerais. Tese de Doutorado, Universidade Federal de Viçosa, Viçosa, MG, Brasil, 181 p.

Claessen MEC (OrG). 1997. Manual de métodos de análise de solo. 2nd ed., Embrapa-CNPS, Rio de Janeiro, RJ, Brasil, 212 p.

Friesen DK, Rao IM, Thomas RJ, OBERSON A AND SANZ JI. 1997. Phosphorus acquisition and cycling in crop and pasture systems in low fertility tropical soils. Plant Soil 196: 289-294.

Gomes JBV, Curi N, Motta PEF, Ker JC, Marques JJGSM AND SCHUlzE DG. 2004. Análise de componentes principais de atributos físicos, químicos e mineralógicos de solos do bioma cerrado. R Bras Ci Solo 28: $137-153$.

LAdD JN, Foster RC, NANNIPIERI P AND OAdEs JM. 1996. Soil structure and biological activity. In: STOTZKY G And Bollag JM (Eds), Soil Biochemistry, Marcel Dekker, New York 9: 23-78.

Lilienfein J, Wilcke W, Vilela L, Ayarza MA, Lima SC AND ZECH W. 2003. Soil fertility under native cer- 
rado and pasture in the Brazilian savanna. Soil Sci Soc Am J 67: 1195-1205.

LOPES AS AND COX FR. 1977. A survey of the fertility status of surface soils under cerrado vegetation in Brazil. Soil Sci Soc Am J 41: 742-747.

Luz PHC, Herling VR, Braga GJ AND Oliveira PPA. 2004. Uso da calagem na recuperação e manutenção da produtividade das pastagens. In: SIMPÓSIO SOBRE O Manejo da PAStagem, Fertilidade do Solo PARA Pastagens Produtivas. Piracicaba. Fealq, Piracicaba, SP, Brasil, p. 63-100.

MACEDO MCM. 2004. Análise comparativa de recomendações de adubação em pastagens. In: SIMPÓsio SOBRE o Manejo da PASTAGEM, Fertilidade do Solo Para Pastagens Produtivas. Piracicaba, Fealq, Piracicaba, SP, Brasil, p. 317-355.

Marques JJ, Schulze DG, Curi, N and Mertzman SA. 2004. Major element geochemistry and geomorphic relationships in Brazilian Cerrado soils. Geoderma 119: 179-195.

Mendonça ES, Rowell DL, Martins AG and Silva AP. 2006. Effect of $\mathrm{pH}$ on the development of acidic sites in clayey and medium Oxisol from the Cerrado Region, Brazil. Geoderma 131: 131-142.

Nachtigall GR AND VAhl LC. 1989. Parâmetros relacionados à acidez em solos da região sul do Rio Grande do Sul. R Bras Ci Solo 13: 139-143.

Novais RF And Smyth TJ. 1999. Fósforo em solo e planta em condições tropicais. Universidade Federal de Viçosa, Viçosa, MG, Brasil, 399 p.

Orlando Filho J, BitTencourt VC, CARMello QAC AND BEAUClair EGF. 1996. Relações K, Ca e Mg de solo Areia Quartzoza e produtividade da cana-de-açúcar. Stab, Açúcar Álcool e Subprodutos 14: 13-17.

RAIJ B. 1991. Fertilidade do solo e adubação. Editora Ceres: POTAFOS, Piracicaba, SP, Brasil, 343 p.

Reatto A And Martins ES. 2005. Classes de solos em relação aos controles da paisagem do Bioma Cerrado. In: Cerrado: Ecologia, Biodiversidade e Conservação. $1^{\text {a }}$ ed., Scariot A, Souza-Silva JC And Felfini JM (Eds), Ministério do Meio Ambiente, Brasília, DF, Brasil, p. $47-59$.

Ritchey KD, Silva JE AND Costa UF. 1982. Calcium deficiency in clayed B horizons of savanna Oxisols. Soil Sci 133: 378-382.

SAno EE, Rosa R, Brito JLS And Ferreira LG. 2008. Mapeamento semidetalhado do uso da terra do Bioma Cerrado. Pesq Agropec Bras 43: 153-156.
Santos HG, Jacomine PKT, Anjos LHC, Oliveira VA, Oliveira JB, Coelho Mr, Lumbreras JF AND CUNHA TJF (EDS). 2006. Sistema brasileiro de classificação de solos, $2^{\text {nd }}$ ed., Embrapa Solos, Rio de Janeiro, RJ, Brasil, 306 p.

SCHIMEl DS, COLEMAN DC AND HoRTON KA. 1985. Soil organic matter dynamics in paired rangeland and cropland toposequences in North Dakota. Geoderma 36: 201-214.

Silva MLN, Curi N, Blancaneaux P, Lima JM AND CARVAlHo AM. 1997. Rotação adubo verde-milho e adsorção de fósforo em latossolo vermelho-escuro. Pesq Agropec Bras 32: 649-654.

Sousa DMG And Lobato E. 2004. Cerrado: Correção do solo e adubação. $2^{\text {a }}$ ed., Embrapa Informação Tecnológica, Brasília, DF, Brasil, 416 p.

Sousa DMG, Vilela L, Lobato E ANd SoAres WV. 2001. Uso do gesso, calcário e adubos para pastagens no Cerrado. Embrapa Cerrados, Circular Técnica, 12, Planaltina, SP, Brasil, 22 p.

SPAIN A. 1990. Influence of environmental conditions and some soil chemical properties on the carbon and nitrogen contents of some tropical Australian rainforest soils. Aust J Soil Res 28: 825-839.

VENDRAME PRS. 2008. Relações entre a mineralogia, fertilidade, acidez e macrofauna em latossolos do cerrado sob pastagem. Tese de Doutorado, Universidade Estadual de Londrina, Londrina, $115 \mathrm{p}$.

Vilela L, MARTha JUNiOR GB, BARIONI LG AND BARCELlos AO. 2004. Adubação na recuperação e na intensificação da produção animal em pastagens. In: SIMPÓSIO SOBRE o MANEJo da PASTAGEM, Fertilidade do para Pastagens Produtivas. Fealq, Piracicaba, SP, Brasil, p. 425-472.

Vitti GC, Lima E and CiCarone P. 2006. Cálcio, Magnésio e Enxofre. In: Nutrição Mineral de Plantas. FERNANDEZ MS (Ed), Sociedade Brasileira de Ciência do Solo, Viçosa, MG, Brasil, 432 p.

Wenzl P, Mancilla Li, Mayer Je, Albert R and RAO IM. 2003. Simulating interfile acid soils with nutrient solution: The effects on Brachiaria Species. Soil Sci Soc Am J 67: 1457-1469.

ZINN YL, LAL R AND RESCK DVS. 2005. Texture and Organic Carbon Relations Described by a Profile Pedotransfer Function for Brazilian Cerrado Soils. Geoderma 127: $168-173$. 